\title{
Developing Children's Cognitive Aspects in Knowing Causation Through Pic- ture and Picture Models, Direct Instruction and Environmental Media in Group B
}

\author{
Nurul Hikmah *, Ahmad Suriansyah, Erny Wahdini \\ Master Program of Early Childhood Teacher Education, Universitas Lambung Mangkurat, Banjarmasin \\ 70123, Indonesia
}

\section{Article history:}

Submission October 2020

Revised January 2021

Accepted January 2021

*Corresponding author:

E-mail:

nurulhikmah.tb@gmail.com

\begin{abstract}
The condition of cognitive ability in knowing the cause of flooding through teacher learning strategies in Tebing Tinggi kindergarten is very lacking. The child does not know the cause and process of flooding in the child's environment. If this problem is not solved, the child's impact will have difficulty in the development of cognitive aspects. It is necessary to develop learning innovations that can develop children's mental elements, especially in identifying causal causes. This study aims to describe the activities of teachers, children, and research improving children's cognitive abilities in identifying the causes and learning activities of children in sorting the series of images by Picture and Picture Model, Live Learning and Environmental Media. The research method used with class action research type (PTK) is carried out in 2 cycles in 4 meetings. The study subjects were children in Group B Mawar Village Tebing Tinggi Sub-District Simpur Hulu Sungai Regency with several 20 children. The research instruments used are the teacher activity sheet, the child activity sheet, and the child's cognitive development results sheet. Qualitative descriptive data analysis with teachers reached $\geq 26$ with the "Good" category, child activity reached $\geq 64 \%$ with the "Active" category, and child development results got $\star \star \star$ star (Growing as Expected). The results of this study relate to teacher activities carried out following the measures set out. Teacher activity scored 40 with "excellent" criteria. Children's activity was classically 95 , with a percentage of $82.25 \%$ in the "very active" category. The development of cognitive aspects of children in knowing the cause of flooding was categorized as very good development $(\star \star \star \star)$ with a percentage of $100 \%$. Advice for teachers, it is expected that this study's results can be used as a guideline to improve the quality of learning in cognitive aspects and children's learning outcomes. As a consideration material, the principal provides more support and guidance to teachers to implement the learning model. For further researchers, to increase creativity in developing the learning process.
\end{abstract}

Keywords: picture and picture, Direct Instruction, Environmental Media, Causation

\section{Introduction}

In the industrial revolution, 4.0 educational patterns emphasized more practice to prepare children and how teachers foster new ideas or new ideas.
This is in primayana's opinion (2019) that teachers have a vital role in child development; there is no denying the planning in learning that needs to be prepared to the fuest. Today

\section{How to cite:}

Hikmah, N., \& Wahdini, E. (2020). Developing children's cognitive aspects in knowing causation through picture and picture models, direct instruction and environmental media in Group B. Journal of K6 Education and Management, 3 (4), 496 - 504. doi: 10.11594/jk6em.03.04.09 
the 4.0 industrial revolution that the government is contemplating is indeed a significant challenge for educators.

In the planning process, teacher's musthave innovation for designed learning to be optimal. It is planning that is the turning point in the smooth and successful education. Other opinions by Wahyudi (2016) that innovation is closely related to the learning process. The learning process involves human beings (read: students and teachers) who have characteristics, namely the desire to develop themselves, progress, and excel.

The industrial revolution of 4.0 had implications for being human in the 21st century, which came into the spotlight not only of economists and businesses but also of the world of education. Students are currently faced with conditions when graduating. They are in the midst of the 4.0 industrial revolution era. Therefore, they must be prepared to deal with it (Zubaidah, 2019). Early childhood education is elementary and very decisive education for the development of children and ensures the continuity of their lives in the future. In the learning process, it is necessary to develop all aspects of its development.

The pattern of education given in kindergarten emphasizes the essence of play for children by providing methods that mostly use the playing system while learning. The materials also vary, including making the child ready to learn, namely ready to learn to count, read and write (Suyanto, 2005). According to Solehuddin (2000), Learning activities are directed to make the child master several knowledge concepts and develop attitudes and interests of learning and various potentials and foundations of the child.

One of the essential skills and needs to be introduced from an early age is the science process skills. According to Nugraha (2008), the development of science learning in children has a very important role in laying the groundwork for human resources' expected formation. Science learning conducted in kindergarten is integrated or comprehensive, so that science learning is integrated with other areas of development. The introduction of concepts in early childhood should also pay attention to the child's level of maturity and ability. In the introduction of the concept of natural symptoms to be applied, students will be introduced to the basic thing about the symptoms of nature reminiscent of the learning of the topic of science, namely firsthand experience. So, the activities given are not abstract science concepts, but rather further develop observation, classification, measurement, numbers, and identification of causation. One of the activities of natural symptom recognition includes causal relationships to allow the child to answer the question "What" and "why" through concrete objects (Suyadi, 2014).

General knowledge and science are among the scopes of cognitive development that exist in early childhood education standards. Science is a knowledge that studies, explains, and investigates natural phenomena in all aspects empirical (Putra, 2013). The activity of knowing science for early childhood should be adjusted to the level of development of the child and based on the description stipulated by the teacher not only introduces science to the cognitive aspect but also the aspects of affective development, psychomotor as well as the activity of the child in the activity of playing science. It is also suggested that science learning for children is more emphasized on the process than on the results.

Based on the initial observations in Mawar Kindergarten of Tebing Tinggi Village Simpur District of Hulu Sungai Selatan district in the school year 2019/2020, from the results of interviews with teachers and observations, it turns out that the results of children's development have not achieved success in knowing the causes of the introduction of natural disasters in the event of flooding.

It is known that the process of science learning is only done through the method of storytelling with the media of images created by researchers, which is followed by coloring images and verbal discussion. This results in the child not having the opportunity to find the facts and concepts themselves, not having the opportunity to develop the skills to process acquisition, so the child cannot name the cause of something happening. As a result of the learning model from 20 children, there are only six 
children who have the cognitive ability in knowing the causes of their environment with the category of Developing as Expected (BSH), five children starting to Develop (MB), and there are nine children in the category of Undeveloped (BB). The expected minimum ability criteria are where all children must achieve a 3star rating $\left(^{* * *}\right)$ with the category Develop Very Well (BSB).

From these data, it can be concluded that a child's cognitive development needs to be improved. The low cognitive ability to know the cause of the consequences about the environment in the event of flooding due to lack of desire and motivation in the child so that the child becomes bored to train his memory and bored in expressing himself in developing cognitive abilities. Based on these problems, there needs to be learning that can improve students' responses to learning. Researchers held discussions with organizers and teachers at TK Melati to improve children's cognitive development by applying the right models and media.

Dale's guidelines noted that providing realistic learning experiences may not be efficient in terms of cost, time, and efforts. Instead, Dale suggested that teachers should balance combinations of concrete and abstract learning experiences. Teachers should help students identify their needs for learning and set clearly defined learning goals related to their needs (Lee \& Reeves, 2006).

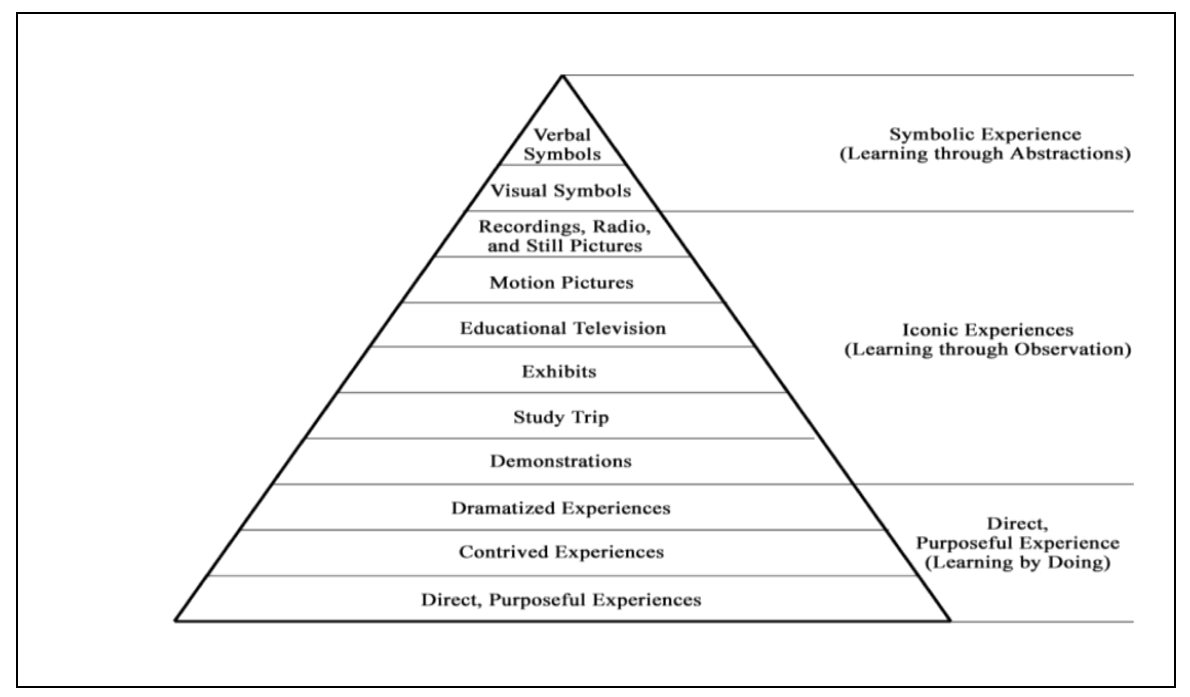

Figure 1. The guided by Edgar Dale's cone of experience in children's abilities

It is guided by Edgar Dale's Cone of Experience in children's abilities. It is thought that using pictures and picture models can provide innovation in learning about the causes of flooding. Based on Edgar Dale's statement, children's ability to see images combined with direct instruction is thought to affect the ability of children to know the cause of flooding. Then include media based on the child's experience.

According to Ormrod (2009), Dale's experience cones classify media based on the learning experience that learners will gain, ranging from first-hand learning experiences. These learning experiences can be achieved through images and abstract learning experiences. The forms of image media in the picture and picture model and direct instruction improve the learning experience to be more concrete. It is hoped that the results of a learning experience about flooding causes are more meaningful for children.

Picture and picture learning model according to Hamdani (2010), picture and picture models are a method of learning that uses images that are paired or sorted into a logical order. But if only with pictures, then students are not enough to develop their cognitive abilities. The picture and picture technique only present images, and students read the images one by one according to the instructions. As a result, the child does not systematically and systematically understand the images presented and 
what events are in the picture. Therefore, learning models that can build children's thinking skills combined with other learning models. One of the models of direct instruction logically and systematically can focus on a procedural concept and declarative knowledge developed so that students' cognitive abilities are improved and can attract children's interest in learning.

Arends (2001) defines direct instruction as a teaching model that aims to help students learn basic skills and knowledge that can be taught in a step-by-step fashion. For our purposes here, the model is labeled the direct instruction model. More opinions by Lefudin (2017) said that as a teaching approach that can assist students in learning basic skills and obtaining information. The empirically direct teaching model is based on the theory of learning derived from a behavior family. The theory of behavioral learning emphasizes behavioral changes as observable learning outcomes. So, learning depends on experience, including providing feedback from the environment.

Research by Khasanah \& Hartono (2015) that there is a significant influence between direct instruction models on visually impaired children's science capabilities at TKLB-A YPAB Surabaya. This is evidenced by the value $\mathrm{Zh}=$ $2.03>$ Ztabel $=1.96, \alpha=5 \%$, then Ho (hypothesis zero) rejected, and Ha (working hypothesis) accepted so that the results of this study have a significant influence.

Additional research by Farchatun \& Indrayati (2015) by implementing a direct instruction learning model in the material of scouting techniques of flood disaster preparedness in Madrasah Aliyah Nahdlatul Muslimin Undaan Kudus is quite good. Students' mastery is seen from the cognitive aspect scores of students who are on very high criteria of $63.3 \%$ and high at $36.67 \%$ as well as psychomotor scores of all students who are on very good criteria.

Other research on different materials is by Marzuki (2016). The results show concludes that the model of direct teaching can improve students' writing ability. Research by Edmonson et al. (1996) stated that the study results showed a functional relationship between the Direct Instruction program and the acquisition of letter sounds. The participant increased his letter-sound correspondence and progressed in early reading skills. By Kardi \& Nur (2000), This real and practical learning model is a direct instruction or direct instruction model. Picture and picture learning models combined with direct instruction that is teacher-centered, provide children with opportunities to learn by selectively observing, remembering, and imitating what teachers model. Therefore, the important thing to note in implementing a direct instruction strategy is to avoid overly complex or broad information/knowledge delivery.

Many kinds of learning media that help and clarify teaching materials as suggested by Usman and Asnawir (2002) stated about the using of media integrated into the learning process because of the function of the media in the activity in addition to being a stimulus presenter in learning, information, attitudes, and others also to increase harmony in the acceptance of learning information.

The media that is expected to be precise with the combination of picture and picture learning models and direct instruction is the media of the child's environment. In the material cause due to the introduction of natural symptoms, namely the onion of flooding, the media that is suspected to be appropriate is garbage cans and water faucets.

In the background above, the researchers took the initiative in conducting this study titled Developing Children's Cognitive Aspects in Knowing Causation Through Picture and Picture Models, Direct instruction, And Environmental Media in Group B. This research aims to describe the activities of teachers and children in the learning process and analyze the cognitive development of children in learning.

\section{Material and Methods}

This research is Classroom Action Research (CAR). CAR is characterized by continuous improvement so that researchers' satisfaction becomes the benchmark for the success of the cycle. Class action research through dynamic and complementary processes is carried out in two cycles with four stages: planning, action, observation, and reflection.

During the observation, the researchers also documented the ongoing learning process 
to determine the child's activities during reflection learning to review all actions that have been implemented based on the data collected, evaluated with the class teacher to perfect the next action. Reflection activities are carried out at the end of each learning activity using fishing playing media. This research was conducted from February 2020 to March 2020 at The Mawar Kindergarten of Tebing Tinggi Village, Simpur District, HSS Regency. This class action study subjects were group B children of 20 children ( 9 boys and 14 women). Selected children in group B1 because of observations and interviews of the cognitive development of children group B1 is not maximal. Of the 23 children, 14 children have not learned the cause and effect of natural events, namely flooding.

\section{Results and Discussion}

Each study consists of 4 stages, namely, planning, implementation, observation, and reflection. This class action is carried out in $2 \mathrm{cy}-$ cles consisting of two meetings. The implementation activities consist of the initial activities, the core activities, and the closing.

In the initial activity begins with the preparation of line-marching activities, singing together, and morning pledges. Before the child enters the classroom, first clean the school environment and clean the sewers and water disposal while explaining that the garbage will cause flooding if left. Then in the core activity that starts by praying and chatting, communicate themes and sub-themes about "the cause of the flood ingestion." Teachers have held simulations by bringing umbrellas to children and teachers in the face of rain and the consequences of prolonged rain and garbage that is not cleaned according to the purpose of learning. The teacher takes the child in the tap area and flows water to the dump where there is dry leaf waste that has not been cleaned by the child so that the child sees the incident that the water from the tap is not flowing.

While in the classroom with a circular, the teacher demonstrates knowledge by showing pictures related to the flooding with the activity of disposing of garbage in the surrounding river. The teacher points/calls one of the chil- dren alternately to post/sort the prepared pictures into logical sequences. The teacher asks the child by stating the reason/basis of the thought of the sequence of the image and giving feedback to the child.

The teacher asks the child to participate in concluding the activity together. The teacher gives feedback in the form of questions about the order of the images, the reasons for the sequence of images that have been provided, and the events that have been experienced by the child.

At the end of the teacher's study with the child concludes the material that has been presented. Teachers give a moral message/ advice that dumping garbage in the river can cause flooding. The results of the learning activities are:

\section{Teacher activity}

The observation of teacher activity at the meeting of 1 teacher obtained a score of 19, which can be categorized quite well. In contrast, the 2nd meeting showed the data increased to 26 with a good category. After analysis based on the Observer results and reflections, improvement efforts were made to the parts of the learning model that had not been fully implemented, so that cycle 2 (two) was carried out as many as 2 (two) meetings.

In cycle 2 (two), there was an increase in teacher activity at meeting 3 , achieving excellent category with a score of 33 , and subsequent improvements to the 4th meeting reached a very good category with a score of 40. This increase is due to improvements in teacher activity in teaching that significantly affect children's learning outcomes and cognitive development. This is seen in the quality of classroom learning in teaching activities that successfully improve teacher activity indicator that increases in each cycle. The model steps are conveyed and explained in detail and directed thus can make the child interested and love learning, and the child looks happy, active, cooperative, and enthusiastic. This study's results are similar to the results of Suci et al. (2018) that implementation of picture and picture learning model in second grade Madrasah 
Ibtidaiyah Darun Najah Kajeksan, Sidoarjo, Indonesia. This can be proved by the increase of score from precycle, cycle I to cycle II. In the first cycle, students who mastery according to MLMS are as many as six students or $46.15 \%$; then, in cycle II, students who mastery as many as 11 students or $84.62 \%=84 \%$. These results also show that implementing the model of learning picture and picture can help the achievement of learning process criteria between teachers and students classified as "good."

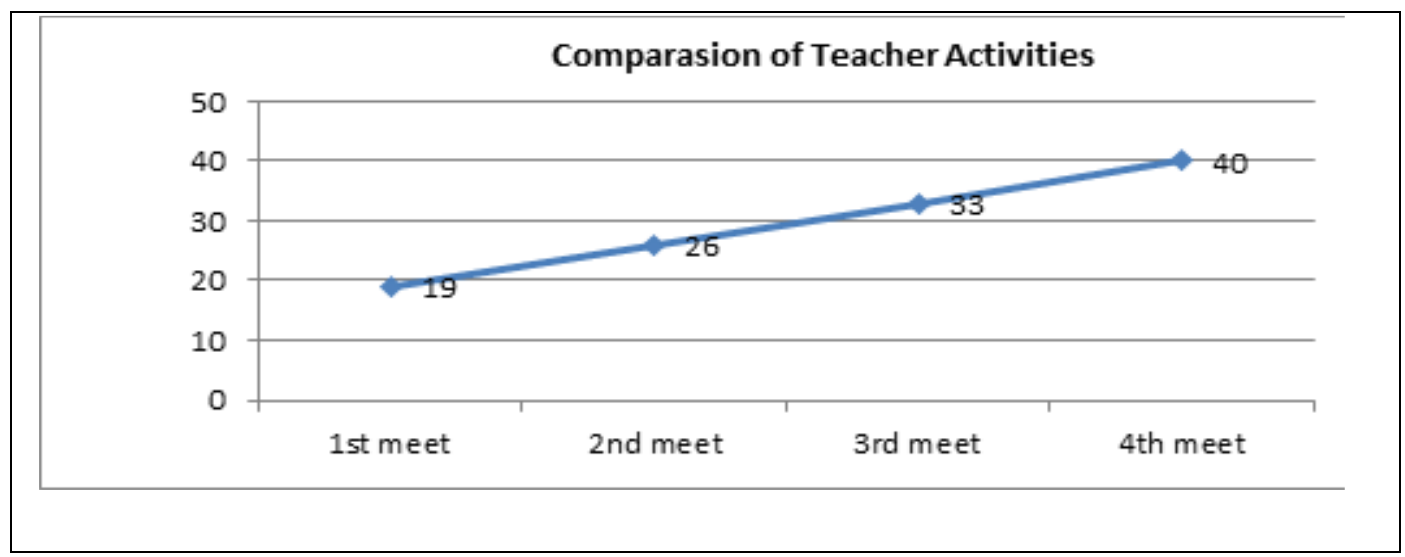

Figure 2. Comparison graphs of teacher's activities in Cycle 1 and Cycle 2

\section{Children's Activities}

Based on observations made known that children's activity from each meeting there was an increase in the meeting, one acquisition of activeness of the child reached a score of 40 classically obtained a percentage of $56 \%$ Activeness of the child. However, there was an increase in the meeting to 2 children's activities increased with a score of 60 classically gaining a percentage of $65.75 \%$. The results of the analysis of children's learning activities are required in cycle 2 (two) to improve the cognitive development of the child in knowing the cause and effect
In cycle 2 of the 1 st meeting, there was a very significant increase with a score of 75 classically gaining a percentage of $72.75 \%$. The results of this assessment were analyzed so that it is necessary to meet 2 with a score of 95 classically obtained a percentage of $82.25 \%$ has exceeded the indicator of success set that is when the activity of the child in courage, enthusiasm, patience, and smoothness and appearance in cognitive development reaches a score of 80 with active criteria.

The increase in children's activity can also be seen in the following graph:

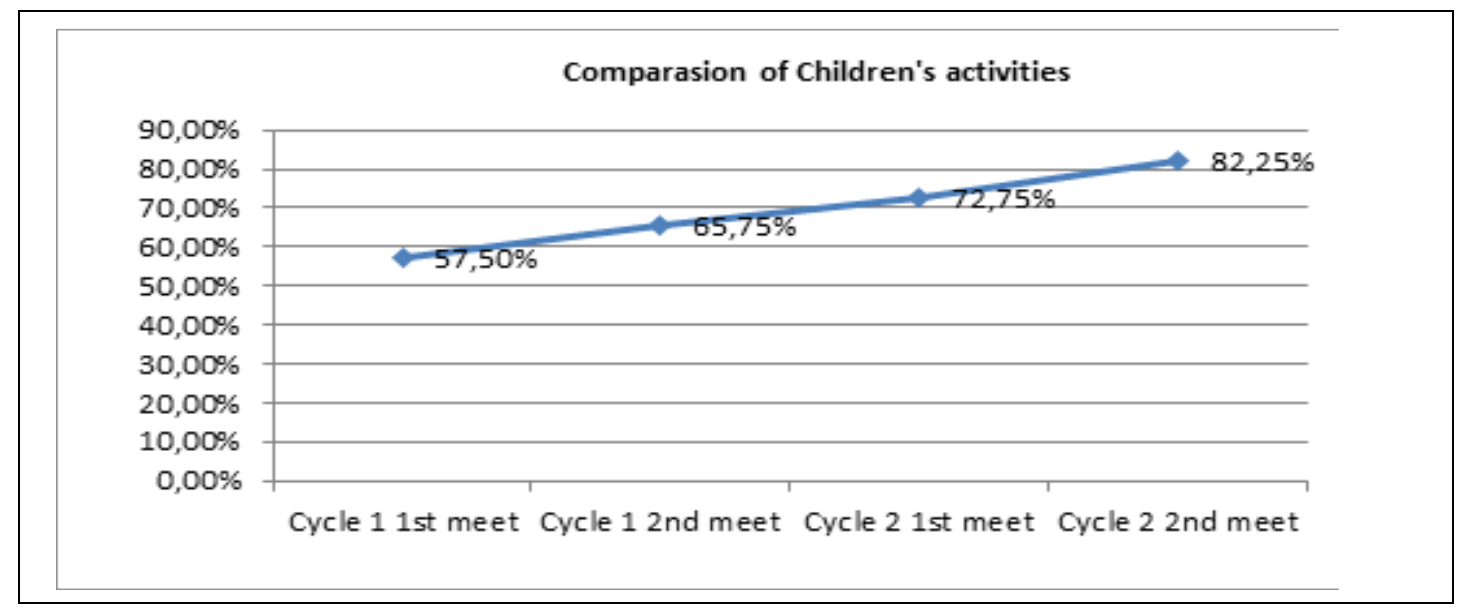

Figure 3. Comparison graphs of children's activities in Cycle 1 and Cycle 2 
The graph above shows the tendency to increase the child's accretion in each meeting during the learning process. This significant improvement was apparently due to the improvement in the quality of learning implemented by teachers. This means that the improvement in the quality of learning by teachers impacts improving the quality and quantity of student activity. The conclusion that can be taken is that if you want students' activities to increase both quantity and quality, quality teachers must carry out the learning process. Whether improving the quality of teacher activity and student activity in the learning process can improve student development outcomes. The following chart can provide a clear and tangible explanation based on the results of field data analysis.

The results of this study are similar to the results of research conducted by Parwati et al. (2013), which implements picture and picture learning model with pictorial number card media to improve the cognitive development of group B children in Widhya Brata Mengwi Kindergarten in Bali on aspects of children's cognitive development. The learning results in cycle I amounted to $53.00 \%$ and increased in cycle II to $93.00 \%$ in the highly active category.

Other research was conducted by Metroyadi (2017) that by applying the picture and picture model as an effort by teachers in developing aspects of religious and moral values of group A children in Azkia Banjarmasin Human Kindergarten so that children can imitate prayer movements. Another study by Safitri and Ratulangi (2018) found those children's cognitive abilities through picture card media in group B in cycle I obtained data from students with bsb (Very Good Development) category of $23 \%$ and BSH (Growing as Expected) by $30 \%$. In cycle II the child obtained BSB (Very Good Development) of $61.6 \%$ and the percentage of BSH (Growing as Expected) by $84.6 \%$.

The use of direct instruction in improving children's activities in children's cognitive abilities is similar to Lawazhim \& Purbaningrum (2015) 4 times with the final result Ttabel=52. The results showed the direct instruction model had a significant effect on a child's cognitive ability to classify group B objects in The Madani Lamongan Kindergarten.

\section{Children's learning development}

The average success of meeting 1 is $20 \%$ gain or $\mathrm{BSH}$, and the increase occurs at the 2nd meeting with a gain of $45 \%$ earned or (BSH) or (BSB). There was an increase in cycle two at meeting 1 with 75\% getting BSH and BSB. At meeting 2 , Cycle 2 , the gain of $100 \%$ got (BSH) and (BSB). From the results obtained, it can be known that the ability of children in Knowing the Cause of Consequences through picture and picture models, direct instruction, and environmental media in Group B increases significantly, meaning that the ability of children's skills in speaking and understanding the content of the story displayed is increasing thus, the ability of children in communicating, socializing and adding new vocabulary also increases. Improved children's language development results can also be seen in the following chart:

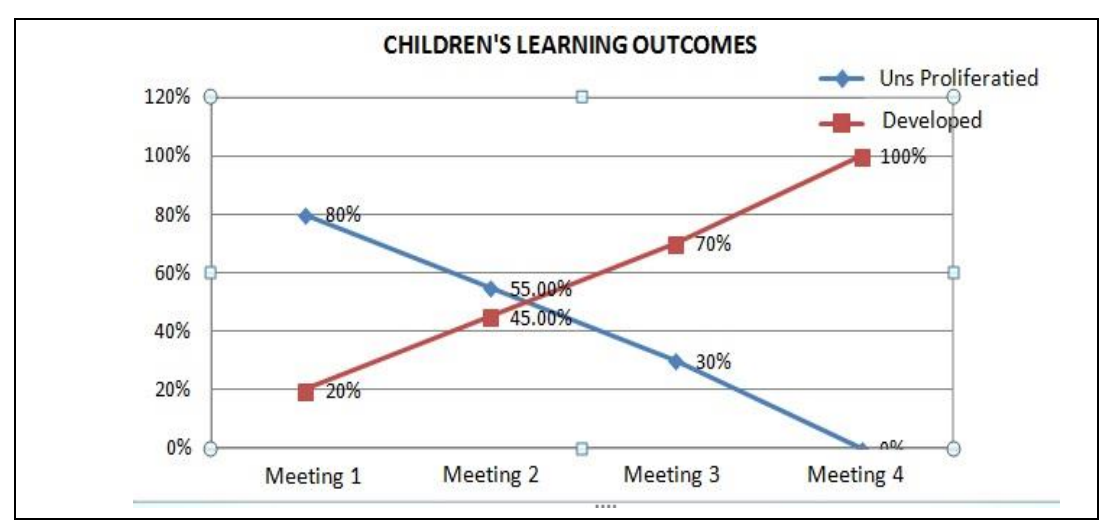

Figure 4. Comparison graphs of children's learning outcomes 
Based on the results of the meeting in cycle I and cycle II, it can be concluded that efforts to develop children's speaking skills in retelling stories/fairy tales that have been heard using knowing the Cause of Causation through Picture and Picture Models, Live Learning and Environmental Media in Group B have achieved indicators of success. This is in contrast to Rochaya and Rohita's research (2014) in the results of children's studies in kindergarten about the causes of flooding and the process by applying project learning methods. In the analysis of cycle, I data obtained $80 \%$ child development data so that it is improved in cycle II with the achievement of children $85 \%$. It is concluded that the method used by teachers in improving the ability of science in knowing the causes of success in children.

Results of Safitri et al.'s research (2018) about Children's independence ability uses the picture and picture model, examples non-examples model and direct practice method of practical life learning activities for children in group B of Kasih Ibu Kindergarten in Banjarmasin are assessed in individually the child is in a very well-developed qualification (BSB) and classically at $95 \%$ of the children are in a very well-developed qualification (BSB). Research by Purwanti et al. (2018) the results of the children's ability to recognize the english language aspects through a combination of picture and picture model, talking stick model, flashcard media, and movement and song method in group B1 in Matahariku Bilingual Kindergarten Landasan Ulin Tengah Banjarbaru individually can be said to be successful, which is developing according to expectation, and developing very well. Then, in classical results, the ability of children to recognize English language aspects are very well developed. Another research done by Fatmasari (2013) stated that students' learning outcomes on space building materials using the Direct Instruction learning model combined with a team game tournament (TGT) have improved.

\section{Conclusion and Recommendation}

As for the results of The Application of Picture and Picture Model, Direct instruction and Environmental Media in Group B can increase teacher activity in learning with excellent category acquisition.

The application of the Picture and Picture Model, Direct instruction and Environmental Media by Knowing the Cause and Effect in Group B can significantly increase children's learning activities in highly active categories.

Learning using the picture and picture models, direct instruction, and environmental media to identify cause and effect in Group B can improve children's developmental outcomes by assessing 15 children developing very well (BSB) and five children developing as expected (BSH).

As for the advice after this research, namely for teachers as reference material to be able to choose a method or learning model that corresponds to the development phase of the child and it is expected to apply the picture and picture model with direct instruction strategies and utilization of the surrounding environment by introducing causation in the child group $B$.

For kindergarten heads, this research should be used to provide more support and guidance to teachers to implement creative learning models in teaching and learning activities in kindergarten.

\section{Acknowledgment}

Researchers thanked the Head of Education Office of Kab HSS, village head and staff at Tebing Tinggi Village, principal, and teacher at Mawar Kindergarten. Thank you for your support and motivation to MPG-PAUD friends 2015.

\section{References}

Arends, R. I. (2001). Learning to teach. New York: Mc. New York: McGraw Hill Companies Inc.

Badriyah, E. B., \& Hartono, W. (2015). The direct instruction model the science skills of visually impaired children. Journal of Special Education, 7(4), 1-9.

Edmondson, A., Peck, S. M., \& McLaughlin, T. F. (1996). The effects of direct instruction on the early reading skills of a kindergarten student. Journal of Precision Teaching and Celeration, 14(1), 72-77.

Farchatun, \& Indrayati, A. (2015). Implementation of direct instruction (direct teaching) learning model of flood disaster preparedness scouting engineering materials in Madrasah Aliyah Nahdlatul Muslimin Undaan Kudus. Edu Geography, 3(5), 5-10. 
Fatmasari, D., Darmiyati, \& Sulaiman. (2013). The use of a combination direct instruction model with a team game tournament (TGT) improves the learning outcomes of the properties of waking up. Paradigm: Journal of Educational Sciences, 8(1), 1-8.

Hamdani. (2010). Teaching and learning strategy. Bandung: Pustaka Setia.

Kardi, S., \& Nur, M. (2000). Direct Teaching. Surabaya: Universitas Negeri Surabaya Press.

Lawazhim, R., \& Purbaningrum, E. (2015). The influence of direct instruction models on cognitive ability to classify objects. PAUD Teratai, 4(2), 1-5.

Lee, S. J., \& Reeves, T. C. (2006). A significant contributor to the field of educational technology. JSTOR: Educational Technology, 47(6), 56-59.

Lefudin. (2017). Learning: equipped with learning models, learning strategies, learning approaches, and learning methods. Yogyakarta: Deepublish.

Marzuki, I. (2016). Escalating ability to write papers: to make use of direct instruction. International Journal of Learning, Teaching, and Educational Research, 15(2), 106-116.

Metroyadi. (2017). Efforts to develop religious and moral values (imitating the prayer movement) through picture and picture models and simulations in the group a Kindergarten Insan Azkia Banjarmasin. Journal of Preschool Education, 1(1), 7-14.

Nugraha, A. (2008). Development of science learning in early childhood. Bandung: JILSI Foundation.

Ormrod, J. E. (2009). Education psychology. Jakarta: Erlangga.

Parwati, N. N., Parmiti, D. P., \& Jampel, I. N. (2013). The application of picture and picture learning with the help of picture card media can improve cognitive development. Journal of Early Childhood Education UNDIKSHA, 1(1), 1-9. doi:http://dx.doi.org/10.23887/paud.v1i1.1041

Primayana, K. H. (2019). Early childhood education learning planning in the face of the challenges of the industrial revolution 4.0. Proceedings of dharma Acarya 1st National Seminar: Challenges and Opportunities of The World of Education in era 4.0. 1, 321-329. Singaraja: STAHN Mpu Kuturan. Retrieved from https://stahnmpukuturan.ac.id/jurnal/index.php/dharm aacarya/article/view/428

Purwanti, R., Suriansyah, A., Aslamiah, \& Dalle, J. (2018). Introducing language aspect (English) to early childhood through the combination of picture and picture model, talking stick model, flashcard media, and movement, and song method in b1 group at matahariku bilingual kindergarten landasan ulin Tengah. European Journal of Education Studies, 5(7), 26-34. doi:10.5281/zenodo.1494188

Putra, S. R. (2013). Design learning to teach creative sciencebased. Yogyakarta: Diva Press.

Safitri, M. E., Ahmad, K. I., \& Saleh, M. (2018). Development of child independence through model picture and picture examples non-examples model and practical method directly involves learning practical life in group b Kasih Ibu kindergarten, Banjarmasin, Indonesia. European Journal of Education Studies, 5(7), 64-80. doi:10.5281/zenodo.1494229

Solehuddin. (2000). Pre-school education base concept. Bandung: UPI.

Suci, S. H., Rosyidah, E., Asitah, N., Aini, N., Murni, A. W., Anam, F., Purnomo, A., Sallu, S., Mulyaningsih, I., \& Kuraesin, A. D. (2018). Learning from picture and picture action research: enhancing counting ability on a division of numbers for primary school students. IOP Conf. Series: Journal of Physics: Conf. Series, 1114, 1-5. doi:10.1088/17426596/1114/1/012044

Suyadi. (2014). Early Childhood Learning Theory in Neuroscience Studies. Bandung: Rosda.

Suyanto, S. (2005). The basics of early childhood education. Yogyakarta: Hikayat Publishing.

Usman, M. B., \& Asnawir. (2002). Learning media. Jakarta: Ciputat Press.

Wahyudi, M. D. (2016). Innovative learning is based on local culture to realize superior schools in preschool education. Proceedings of The National Seminar of PS2DM ULM. 2, pp. 12-17. Banjarmasin: Lambung Mangkurat University. Retrieved

from https://rumahjurnal.net/index.php/PS2DMP/article/vie $\underline{\mathrm{w} / 746}$

Zubaidah, S. (2019). STEAM (Science, Technology, Engineering, Arts, and Mathematics): learning to empower 21st-century skills. National Seminar on Mathematics and Science with the theme "STEAM Integrated Local Wisdom In The Face of Industrial Revolution Era (pp. 1-18). Indramayu: Universitas Wiralodra. Retrieved from https://www.researchgate.net/profile/Siti_Zubaidah5/p ublication/336065211_STEAM_Science_Technology_Engi neering_Arts_and_Mathematics_Pembelajaran_untuk_Me mberdayakan_Keterampilan_Abad_ke-

21/links/5d8cb46ea6fdcc25549b33aa/STEAM-ScienceTechnology-Engineerin 